\title{
MANAGING CHANGE IN HIGHER EDUCATIONAL INSTITUTIONS IN SOUTH AFRICA: SOME CHALLENGES
}

\author{
L Froneman (CACC)
}

\begin{abstract}
Higher Education has a vital role in developing an internationally competitive economy, a more affluent society and a sturdy democracy. The newly released National Plan for Higher Education in South Africa should recognise the current social and economic status in the country to realign its mission, and to reconsider the location and target audience of the various institutions in the country, to optimally serve the educational needs of the communities. The proposals in the National Plan, however, attempts to attain in a few years what other stabilised countries took years. That poses major challenges to education management.
\end{abstract}

The aim of this paper is to evaluate some aspects of the managerial skills in the national education authorities. By analysing the National Plan, and testing the views of a number of teaching staff, the conclusion is that there are serious doubts regarding the management acumen in the educational leadership and that various important aspects are left out in the Plan.

Keywords: Higher Education, management acumen

\section{INTRODUCTION}

In the words of Battin "... the network is changing how we work, live and educate. In fact, it is fundamentally changing many of the rules of competitiveness. In the networked world, traditional rules no longer apply, boundaries disappear, ambiguity prevails and the foreseeable future is of no use at all" (Smit 2000:8).

Higher Education is one of the most rapidly changing sectors of our society (Brunyee 2001:1). In recent years the environment in which higher education has had to operate has become increasingly complex, uncertain and turbulent, and has manifested an ever-increasing rate of change (Bruyns 2001:1). The environment of changes are due to for example, growing global competition, shifting stakeholder expectations, technological development, economic restructuring, different work and management practices and social reconstruction.

At the beginning of the 90 s, the renowned educationist Clark Kerr remarked that " $\ldots$ for the first time a really international world of learning, highly competitive is emerging" (Smit 2000:8). Higher Education in Sub-Saharan Africa is experiencing an unrelenting pressure to expand access opportunities to learners, but at the same time improving the present educational quality without prospects for better funding possibilities. This fundamental imbalance between funding, standards and enrolment for students is caused by multiple reasons, e.g. overcrowded lecture 
rooms, irrelevant and outdated curricula, and poorly learning facilities. Due to high population growth, the number of African students seeking entrance to higher education will surge during the coming years. Only a few of them can be accommodated under present conditions. Consequently, Higher Education in Africa becomes a volatile issue in Sub-Saharan Africa, and can easily be drawn down into the local and international political arena. In the words of Saint "... it is time for governments to anticipate the rising chorus of such demands, and to take steps which will ease the pressures for access while upholding the national interest in good quality higher education and responsible stewardship of national resources." (Saint 1999:1)

In South Africa, higher education institutions are confronted with a myriad of new policies, legislation and qualification frameworks. These are governmental institutional community and student demands for new political awareness and commitment, the "Africanisation" of curricula and the addressing of language issues (Greyling 2001:2).

The NCHE (National Commission on Higher Education) was charged with advising the government of national unity on issues concerning the restructuring of Higher Education (HE) by under taking a situation analysis, formulating a vision for $\mathrm{HE}$ and putting forward policy proposals designed to ensure the development of a well-planned, integrated, high quality system of HE (NCHE 1995a:1).

The restructuring of South African higher education, according to the NCHE (1995 a:1), needs to address the inequalities and inefficiencies inherited from the apartheid era and to respond to the new social, cultural and economic demands. Of particular importance are the demographic and socio- political demands for $\mathrm{HE}$, the changing skill and knowledge requirements for improved productivity and innovation and contribute to a new citizenry.

Managing the successful change entails the permanent transformation of the 'what is' state of higher education into a 'what should/must be' state. In this paper, the National Plan for Higher Educational Institutions (HEI) in South Africa have been analysed and the influence of Educational Leadership on the National Plan and focuses on various important aspects that are left out in the Plan. The purpose of this paper will therefore be to discuss key components and critical issues relate to managing change in $\mathrm{HEI}$.

\section{HIGHER EDUCATION}

Higher Education is a vitally important activity in any modern society. However, educational institutions in Africa are not expanding and accommodating enough for the increasing number of students. Africa needs an educational environment that would make it more responsible to challenges confronting the continent (Darkwa \& Mazibuko 2000:2). 
According to the NCHE (1995b:4) higher education consist of "... all learning programmes leading to qualifications that represent a level of learning which is higher than the present matriculation or higher than the further education certificate in the National Qualifications Framework (NQF)."

The following are the most important purposes related to higher education:

- It meets the learning needs and aspirations of individuals through the development of their intellectual abilities and aptitudes.

- It equips individuals to make the best use of their talents and the opportunities offered by society for self-fulfillment. Higher education is thus a key element to facilitate change in peoples' lives and in the well being of a country.

- It provides the labour market, in a knowledge-driven and knowledge-dependent society, with the high-level competencies and expertise necessary for the growth and prosperity of a modern economy.

- It teaches and trains people to fulfil specialised social functions, enter the learned professions, or pursue vocations in administration, trade, industry and the arts.

- It is responsible for the socialisation of enlightened, responsible and constructive critical citizens. Citizenship of this nature presupposes a commitment to the common good, but it also implies a reflective capacity and a willingness to review and renew prevailing ideas, policies and procedures.

- It is directly engaged in the creation, transmission and education of knowledge. Its purpose is to ensure the continued pursuit of academic scholarship and intellectual inquiry in all fields of human understanding, through research and teaching (Draft White Paper 1997:3).

Dramatic changes took place In South Africa over the past ten years in the higher education sector. There are a number of new entrants that have established themselves in competition to traditional (public) institutions. This has led to a change in the demographics of student enrolment in higher education institutions.

The South African Government has introduced a process of quality control and regulations. Two important acts were introduced, namely the SAQA (South African Qualifications Authority) Act of 1995, and the Higher Education Act of 1997. These acts require all institutions, private and public, to supply required information and undergo a specific process of quality control and registration. The number of institutions operating in the field of $\mathrm{HEl}$ is not clear. "... education can essentially be characterised as a set of markets where educational institutions supply students, knowledge, and other services. Knowledge can either be created, transferred, or modified" (Tschang 1997:5).

A higher education system can be considered to be a set of institutions operating within an environment, and possesses a set of internal objectives. The institutions have traditionally justified the pursuit of higher education by a number of important goals, such as: 
- Private goals: The market demand for educated labour.

- Public goals: The development of national capacity. Public goals are sometimes associated with private ones, such as when governments are interested in supplying the skilled labour that markets desire. In developing countries the concern, to be argued is that a œrtain amount of educational capacity is necessary for countries to develop economically. It may involve longer-run/term goals and require more public resources.

- Knowledge of education for the society: The knowledge for ethical purposes.

- The intellectual pursuit of knowledge: Seeking of knowledge for its own sake, or out of personal curiosity.

With the role of the government in providing certain functions such as education, was recognised only from this century. Today, even public educational institutions like universities will exist in a fuzzy private-public nexus containing partnerships, contracts with the private sector, and markets. The private sector is also the scene of much intellectual activity for both the public sector and the social good. Blaug (1994) said that "Nonetheless and irrespective of the many motivations that can exist, the bottom-line in the private sector and nowadays even in the public sector, is often economic feasibility." Economics does not simply reflect financial considerations, since reputation and other effects can motivate a university to undertake longterm projects.

The world is undergoing a fundamental change in economic structure as the globalisation of markets takes place and competitive forces are unleashed across national borders. Globalisation refers not only to trade and economic expansion, but also to labour force mobility and the changing needs of students and corporations from all over.

These forces have affected the higher education system, particularly institutions in the developed countries that compete for students and research funds, and most so in highly developed market economies. In many countries and educational systems, market forces have turned higher educational institutions into companies within an industry supplying "products" and "services" to "markets."

Globalisation increases the competition amongst institutions, causing institutions to better manage inputs and resources to maintain their financial well being as they meet the demands of markets. The process of meeting demands by creation of knowledge or student who embody the knowledge, involves transforming a set of inputs into outputs.

Globalisation is the "... increasing intensification of world-wide social and economic relations which link distant places and communities in a network of interdependence and interactions such as that local happening are shaped by remote event and world affairs are conversely affected by things that occur in local, national or regional context" (NCHE 1995b:7). 
It is important to recognise the changing nature of demand for education as a force behind changing institutional responses. Public institutions may have non-profit motivations for seeking knowledge, and most of all these institutions will have to figure out how to channel those motivations into financially sound operations. There are numerous ways in which knowledge can be created stored and transmitted. The traditional means of creating knowledge in $\mathrm{HEl}$ are well known, consisting of teaching, training and research. Some of the ways in which knowledge is generated include: deliberation, experimentation and interaction.

\section{Different forms of Higher Education Systems}

"Moat developed countries and also countries that were developing rapidly, reshaped their higher education system in the period from the 1960s to the 1980s" (NCHE 1995d:1). While this reshaping took various forms, the fundamental imperatives arose from the modernisation of society and the economy. The process began with expansion of the university system, through creating bigger institutions and building new ones, and secondly through the provision of alternative models and types of Higher Education. This set in motion a movement from "University-dominated" systems to dual systems consisting of universities and alternative institutions. In many countries this resulted in a binary system in which the alternative institution constituted paralleled Higher Education sector. While the intention was that the two sectors should be complementary, in many instances they became competitive.

The outcome of this development was either a "unified system" (a comprehensive Higher Education System including all systems) or a "stratified system" (a common system with differentiated institutional missions and status). While there are many forms of Higher Education $(\mathrm{HE})$ there are common elements in the evolution of systems in Higher Education. The challenges facing $\mathrm{HE}$ in the 21 st century may more easily be addressed through formally unified but highly differentiated systems than in dual or binary systems.

\section{South African Higher Education System}

The South African Higher Education exhibits dual and binary characteristics. The universities and technikons are complementary sectors with formally equal status but with differentiated missions. The binary distinction is between the universities role in general formative and professional education and is basic and applied research. While the technikons role is in vocational and career education and product-related research and development.

The NCHE (National Commission on Higher Education) point of departure in constructing a new framework for South Africa Higher Education. The challenges outlined, cannot be met by the structures and policies inherited from the past. The NCHE has identified three profound shifts which are under way in the larger global community but which are also emerging in South Africa. 
However there are implications for movement towards a single coherent and co-ordinated national system of higher education (NCHE 1995d:2). The South African Higher Education (SAHE) has defined it in relation to three distinct segments, university, technikon and college. A conventional wisdom has developed over the roles of these three sectors. The policy implementation and legislation in HE has been informed by this conceptual framework for the past three decades without any effort to overcome what one submission aptly described as "... an uneasy cohabitation of a deeply divided university sector with almost entirely separate college and technikon sectors." According to the Commission of the NCHE (1995d:2) this has occurred at great cost to higher education in South Africa, because the current trinary model is severely flawed in that it is institutionally fragmented with rigid boundaries, little articulation across sectors, and with not national overall plan.

This position is unlikely to survive the fundamental transition taking place in South Africa Higher Education. The most significant impact of these changes is the dilution of previously impermeable boundaries between the three sectors as reflected in a multitude of cross-sectoral linkages and partnerships; new forms of programme offerings and student progression pathways; new forms of assessment and delivery modes such as lifelong learning, distance education and recognition of prior learning, which span all three sectors; and new forms of knowledge construction which are developing that require the softening of the boundaries within higher education and between higher education, civil society and the state (NCHE 1995d:2).

It is clear that the new higher education system will be characterised by seemingly contradictory impulses. In most modern countries higher education has become more dynamic and volatile than ever, with multiple pressures reshaping its contours. Higher education today is far more permeable, responsive and open, with system boundaries less clear and less stable than during the elite era. In most modern higher education systems today, there are dynamic movements and counter-movements towards and away from single system structures.

According to the commission managing changes in the HES there are four conditions necessary for a pragmatic and effective transition to a single, co-ordinated system of higher education (NCHE 1995d:3):

- Firstly, the need for a shift in thinking away from boundaries and an emphasis on the precise contours of each sector, to a focus which is strategically centred on developing an effective regulatory environment which puts in place mechanisms of co-ordination and articulation and which establish flexible methods of allocating programme offerings across the entire system.

- Secondly, for effective transition to a single system is the need to recognise current strengths, weaknesses and the existing bodies of knowledge embedded in current institutions and plan accordingly. 
- Thirdly, co-operative governance requires consensual forms of moving the entire system forward. New roles and missions cannot be prescribed by the government alone without due regard for institutional capacity and institutional co-operation.

- Lastly, for effective transformation is beginning to specify clear regulatory or steering mechanisms which can be implemented in the short to medium term, and which can begin to direct the current higher education structure towards amore coherent system.

\section{NATIONAL PLAN FOR HIGHER EDUCATION IN SOUTH AFRICA}

The White Paper on Education and Training stated that "South Africa has achieved by a large measure, the most developed and well resource system of education and training in Africa. The quality of South Africa's diploma, degree, postgraduate and research output was created and sustained the country's sophisticated economic and financial infrastructure industrial, business and communications technology and medical, legal, cultural and other professional services" (NCHE 1995c:1).

According to the NCHE (1995c:), this statement is particularly true of certain institutions which have managed to develop internationally competitive research and teaching capacities and to produce high quality professional training programmes. While most of this capacity is located at the historically white institutions, some of the historically black institutions have developed expertise in certain academic areas and in the area of community outreach and research into basic community needs. It would be detrimental to the national interest and the future provision of quality $\mathrm{HE}$ if the valuable features and achievements are not identified, retained and utilised in the process of restructuring.

Asmal (2001:2) stated that “... it is vital that the mission and location of HEl be re-examined with reference to both strategic plan for the sector and the educational needs of local communities and the nation at large in $21^{\text {st }}$ century."

The National Plan for Higher Education (NPHE) was culmination of wide ranging policy process for the transformation of the HES, which started in the early 1990s. The NPHE provides a framework for implementing the policy proposals contained in Education White Paper 3: A programme for the transformation of HE, which was released in July 1997.

The White Paper's central proposition is the creation of a single national co-ordinated HES that is planned, governed and funded as a single system and is underpinned by two inter-related factors (Department of Education 2002a:8):

- The need to overcome the apartheid-induced fragmentation inequalities and ineffciencies, which distorted the development of the HES and its ability to address the knowledge human 
resource and social and economic needs of the country. It is resulted in structural inefficiencies through the duplication and overlap of programme offerings, management structures and administrative and other services, which continue to hamper the HES.

- The challenges of reconstruction and development in the context of globalisation and its impact on knowledge and skills development as well as on the world of work.

The structural inefficiencies, furthermore have given rise to a range of systematic problems, which adversely impact on the effectiveness and efficiencies of HES. These problems relate to overall quality and quantity of graduate and research outputs; management, leadership and governance failures; lack of representative staff profiles; institutional cultures that have not transcended the racial divides of the past; and the increased competition between institution which threaten to fragment further the HES.

The White Paper argues that the goals of a single national system requires an assessment of the optimal number and type of institutions needed to ensure HES which is, on the one hand affordable and sustainable and on the other to contribute effectively to social and economic development (Department of Education 2002a:8).

The restructuring of the HES in South Africa was done by the National Working Group (NWG) who advise the Minister of Education on a regional basis through the develo0pment of new institutional and organisational forms, including institutional mergers and rationalisation of programme development and delivery.

The purpose of the NWG is to investigate and advise the Minister on appropriate arrangements for consolidating the provision of HE on a regional basis through establishing new institutional and organisation forms, including the feasibility of reducing the number of HEI. The investigation forms part of the broader process for the restructuring of the HES to ensure that it contributes to social and economic development, as outlined in the NPHE.

According to Asmal (2002b:1) the NWG has produces an excellent report that provides the basis for taking forward the restructuring of HES to enable it to respond to the equity and development challenges that are critical for improving the quality of life of all people. The further improving the quality of life of all people. He further stated that he is impressed with the fact that while sensitive to the historical and political complexities involved, the report has not allowed these complexities to stand in the way of advancing a bold framework for the restructuring of the HES.

The NWG took as its point of departure the emphasis in the NP on the need to ensure the fitness for purpose of the HES, that is, the extent to which the elements constituting the structures and operations of the systems are suited and well equipped to fulfil effectively those functions which are its raison d'être thus enhancing the quality of the HES. 
The White Paper on Higher Education (Department of Education 1997) gives the following outline of the raison d'être (or purpose of definition functions) of HE:

- To meet the learning needs and aspirations of individuals through the development of their intellectual abilities and aptitudes throughout their lives.

- To address the development needs of society and provide the labour market with the ever changing high level competencies and expertise for the growth and prosperity of a modern economy.

- To contribute to the socialisation of enlightened responsible and constructively critical citizens.

- To contribute to the creation, sharing and evaluation of knowledge, through the pursuit of academic scholarship and intellectual inquiry in all fields of human understanding and through teaching and learning.

The NWG's recommendations are two-fold. The first relate to a number of general issues, which cut across all regions. The second is a set of proposals and recommendations for the consolidation of $\mathrm{HE}$ provision on a regional basis through establishing new institutional and organisational forms, including a reduction in the number of HEl from 36 to 21 through mergers.

The NWG believes that the implementation of its recommendations will result in the fundamental restructuring of the HES. It will transform the apartheid edifice of the HES and lay the foundation for a HES that is consistent with the vision, values and principles of our young and vibrant democratic order (Department of Education 2002a:7).

Higher education and public higher education especially, has immense potential to contribute to the consolidation of democracy and social justice, and the growth and development of the economy, despite the problems and challenges it faces.

These contributions are complementary. The enhancement of democracy lays the basis for greater participation in economic and social life more generally. Higher levels of employment and work contribute to political and social stability and the capacity of citizens to exercise and enforce democratic rights and participate effectively in decision-making.

The overall well being of nations is vitally dependent on the contributions of HE to the social, cultural, political and economic development of its citizens (CHE 2000:25-26).

\section{ANALYSING THE PROPOSALS OF THE NPHE}

In many African countries, the education that is provided is of poor quality. Because there are not enough funds to cover the basics: lecturers, buildings, materials, and it is a consequence of earlier rapid expansion: large numbers of lecturers are untrained or undertrained. How else could children be accommodated in schools, but by recruiting more and more people to teach 
them? And as a result those children who complete school are unlikely to have a better grasp of the subjects they have studied than had the lecturers who taught them. In-service training for these lecturers can have a substantial effect on quality.

According to Jenkins (1989:2) the crisis in education is serious: "Because of the invidious combination of rapid population growth and economic stagnation, the gap between SubSaharan Africa and the rest of the world appears to be widening unless steps are taken to address the serious problems in education, this gap will in time become a gulf." Fullan (1993) stated that "Unanticipated changes in the course of any plan or project are guaranteed. They are not abnormal intrusions but part and parcel of the dynamic complexity of present society."

Although change may be embedded in the policies, legislation and frameworks there is often little evidence of real transformation at nstitutions. Audits and research into the educational system and educational management in general, reveal dysfunction's between visions and realities due to the interplay of a complex web of factors (Greyling 2001:2). These include the enduring influence of structures and systems of a fragmented and discriminatory past, passive or hostile resistance to change and adequate resources to achieve significant and sustainable change. Since August 1999, all HEI have embarked on training and development activities, focusing on the regulations of the Skills Development Act (no. 97 of 1998) and the Employment Equity Act (no. 55 of 1998).

In this contribution academic freedom as guaranteed by the constitution are explodes, argue that academic freedom is a central feature of a university in a democratic society which should be respected by all stakeholders. The NQF and SAQA (South African Qualifications Authority) directives, initiatives limit academic freedom unconstitutionally. The government and universities should be founded in order to uphold academic freedom without paralysing the government's efforts to transform education for the benefit off all.

In the rush to generate and register standards and qualifications in terms of the NQF (National Qualifications Framework) and establish bodies to assure the quality of education and training programmes, little attention is being paid to the concept of academic freedom. Although access to HEl sporadically feature in the public discourse, the absence of any significant reflection on the impact on the NQF on academic freedom is cause for serious concern (Malherbe \& Berkhout 2001:3).

Asmal (2002a:13) said that "What we are carrying out is the government's transformation agenda. For me that is important enough to enthuse and energise rather than embattle me. It is important to consider areas of sensitivities only if they are not going to lead to paralysis and indecision about what needs to be done. They also should not be used as a guise to hide selfinterests and the need to hold on to our sad past. I also trust that we shall all transcend our 
differences and focus on bringing about an academically viable and economically and socially relevant system of HE for the general good of all the people of our country."

According to Kahn (2002:14) "The government appointed working group that drew up the report (that regional consolidation of 36 universities and technikons into 21 instituiton 0 is likely to give Asmal the political backing, he needs, to push through a radical restructuring of the higher education landscape." Macozoma (Kahn 2002:14) said that that the rural location of many the black universities meant that they would never be sustainable in their current form, due to declining student numbers and the inherent difficulties in recruiting staff to such isolated locations.

The report recommended that academic programmes of Unitra (University of Transkei) be discontinued, with the exception of its medical courses, which would be absorbed by a proposed institutional merger between Rhodes University and Fort Hare. The report proposes that the University of Zululand become institution offering technikon style courses geared to the needs of the industrial node of Richards Bay.

Many of the proposed mergers come as no surprise to educationalist, as they were discussed in two previous documents:

- $\quad$ Size and shape report of the council of HE in 2000

- National Plan for Higher Education in 2001.

According to Monare (2001:13) "In 2006, prospective students will no longer apply to universities or technikons for the sake of prestige and academic reputation of the institution but on the basis of the establishment's area of specialisation." This is, if the Ministry of Education achieves its goal on the "Diversity and Differentiation" by letting institutions concentrate on areas suitable to their social environment. Institutions will be differentiated on the basis of specialisation, programmes offered and the main distinction between technikons and universities will remain, for now.

The Ministry (Monare 2001:13) said in the document detailing the plan that "The danger with the structural differentiation is that it introduces an element of rigidity, which will preclude institutions from building their strength, and responding to social economic needs, including labour markets needs." This victory for leaders of black institutions and students organisations whose fears of being marginalised to the mediocre fringe of academia seem to have been allayed (Monare 2001:13).

Universities and Techikons have been given five years to continue with their current programmes but at the same time demonstrate the capacity and strength in intended specialised areas. The same thing the ministry wants to avoid is that of perpetuating the apartheidstructured institutions, which may result if capacity, which may mean staffing, financials and 
resource power, is used as criteria to approve their specialisations. The ministry disagrees, the deputy director-general: higher education, Badsha said (Monare 2001:13) that "There will be engagement with institutions in order to reach agreements on what their profile will be. And that will be the basis for funding for those particular institutions. We will definitely support them. Institutions will be identifiable by what they are best at and not historical reputation and prestige, whose distinctive features may disappear. The starting point of restructuring must be to ensure that higher education institutions as they are currently structured, become more efficient and effective before embarking on roles on the future."

The Minister of Education, Kader Asmal (Siweya 2002:7) claims that these mergers are part of the broader government-initiated transformation. The message sent by Cabinet to the Minister is clear: Never again will the future of our education system be left in the hands of one individual.

Anywhere in the world, education is the most important tool with which nations fight poverty, a means through which human advancement can be brought about. In going about educational transformation the minister should have been advised to start with the school system and adult basic education, because there is no way in which the government can fight and alleviate poverty without taking them out of their quagmire of illiteracy (Siweya 2002:7).

Van der Meer (2002:7) said "The draft Education Act interferes with the individual's freedom of choice, and is probably unconstitutional."

Educational institutions such as Universities can not be expected to carry out their mandates when the Minister constantly interferes with their management. The Minister of National Education now holds Higher Education hostage. Does it mean that in proposing amendments to the Higher Education Act, thereby empowering himself to appoint university administrators, the minister has misled his colleagues?

In the absence of any known accounting procedures for university administrators, is the minister premising that his heirs are immune to corrupt practices? Doesn't it mean that even if there is an impropriety by these heirs to the minister's empire, such practices are likely to be swept under the carpet? The latest development in the minister's transformation agenda makes one wonder whether this is not a case of "in the land of the blind the one-eyed man is king?"

What the minister does not want to acknowledge is the simple fact that in creating superstructures (like his proposed mergers), when a superstructure crumbles so does everything on which it is founded. The Minister has targeted the historically black institutions, badly managed, as some have been, survived the apartheid regime and for him, to wish them away is beyond comprehension. They are an integral part of the noble ideas conceived by people of this country in rising against injustices of the past, according to Siweya (2002:7). 


\section{CHALLENGES FOR EDUCATION MANAGEMENT}

The challenges currently confronting higher education in Africa do not exist in isolation.

They form part of the broader economic, technological and educational changes in the world at large. The emergence of a global knowledge-based economy is being accompanied by an increasing willingness by governments to invest in education (Saint 1999: 2).

Porter (1985:13) describes the effects of 'third wave economic' giving rise to highly flexible and rapidly changing business environment, which are becoming agile and virtual organisation are described by Reid (1999:3) as an example of a response for a range of forces, including the following:

- Market fragmentation

- Demands for production to order in arbitrary lot sizes

- The capacity of institutions to treat masses of customers as individuals

- Shrinking product lifetimes

- Convergence of physical products and services

- Global production networks

- Simultaneous inter company co-operation and competition

- Distribution infrastructures for mass customisation

- Corporate reorganisation frenzy

- Pressure to internalise prevailing social values.

Within this model, according to Reid, mass produced, standard products are replaced by mass customised, products, product management is replaced by skill and customer management, businesses compete on value to customers and competencies of teams rather than on cost and quality alone, products are increasingly information rich. The development of strategy for managing change in educational institutions, is clearly impacted upon by the above forces, and the teaching and learning resources, viewed as products and the methods of their production on within this paradigm, will need to have these characteristics if the educational institutions is to compete with other institutions within this highly fragmented and interconnected marketplace.

The changes in the political and economic systems are all affecting the challenges of higher education. The higher education system in South Africa is challenged by government to respond to the demands for increased participation in education to respond to societal interests and needs as well as to promote co-operation and partnerships in governance. Management in higher education institutions appears to be concentrating on the structural changes needed while ignoring the challenges of the new century (Pretorius 2001:4). The major dilemmas or requirements of co-ordination relating to education, which needs to look at the significant 
transfer of knowledge, and learning to communities. At the same time the global trends and challenges must be kept in mind. One of these challenges is the direction of science and technology.

The role of professional development in education institutions, according to Bradley (1997:12) "... the staff developer needs to understand the strategic goals of the institutions indeed be part of the developments of these goals, and be able to engage in strategic application of their skills so that their impact is not marginalisation or limited by individual consultative action. Achieving this is not easy as it means re-appraising roles of both staff developers and of other within institutions."

The time for walking is past. It is time to look at ways of co-operation and planning together.

\section{CLOSURE}

Governments of African countries and especially their ministers of education can expect that if they make an effort to develop their higher education capacities, they might have a glimpse of the future of global higher education.

Recent "massification" trends of higher enrolments in the development countries will continue and expand to engulf the developing world as well. Lifelong learning will become the global norm as both countries and workers strive to build and maintain a competitive edge.

The future for learning will be greatly individualised and self-managed by students. Therefore resulting in those highly professional student guidance systems becoming a central element in higher education (Saint 1999:36).

The NCHE document focuses on the macro issues by providing an overview of the South African situation, discussing international trends in Higher Education, posing some principles and goals and proposing a new framework for the system. The question is have the above been accomplished? As the NCHE (1995a:4) said that "This document is not intended to be comprehensive since it is part of an ongoing process."

The need for managing change in HEl is enormous and part of the legacy of apartheid. It is easy to blame apartheid but the real challenge lies in dealing with the change in HEI. Many of South Africans are unemployed and have no means to generate an income. HE does not cause development or economic growth and economic growth and cevelopment cannot take place without HE.

The suitability of the existing national plan needs to be constantly scrutinised and when necessary challenged and contested. The national plan has been enacted and is too often the 
case, it is adhered to dogmatically rather than reviewed and changed when necessary. The national needs to be open to ongoing evaluation and change, more creative, maximise available resources, be less bureaucratic and regulatory and generally more appropriate to the South African context.

Van Niekerk (2001:1) states that "The reconstruction and development plan, the multiyear implementation plan, the South African literacy Initiative, and the many political promises have not materialised admittedly, that it is only seven years since the advent of democracy."

A closer co-operation amongst South African institutions for Higher Education in South Africa is necessary to develop a national strategy for Higher Education. Higher Education Institutions have the potential to play a critical role in the African Renaissance.

\section{BIBLIOGRAPHY}

ASMAL K. 2001. Foreword: National Plan for Higher Education. Department of Education. Pretoria.

ASMAL K. 2002a. Description of Education Minister as "embattled' is totally inaccurate. The Star. 13, 14 May.

ASMAL K. 2002b. Foreword: The Restructuring of the Higher Education System in South Africa. Department of Education. Pretoria.

BLAUG M. 1994. Economics of Higher Education in the role of the University: a global perspective. United Nations university and UNESCO.

BRADLEY D. 1997. Staff Developer as Strategist. Paper delivered at he AHED Forum, New Millennium, Four Winds, AHED of change, Adelaide, July.

BRUNYEE LR. 2001. Managing in the rapidly changing context of Higher Education: a manager, as 'reflective practitioner' reflects on some experiences. [INTERNET: http://inasp.org.uk/ajol/journals/sajhe/vol15no2abs.html.]

BRUYNS HJ. 2001. A model for managing large-scale change: a higher education perspective. [INTERNET: http://inasp.org.uk/ajol/journals/sajhe/vol15no2abs.html.]

COMMISSION ON HIGHER EDUCATION (CHE). 2000. Toward a new Higher Education Landscape: meeting the equity, qualities and social development imperatives of South Africa in the $21^{\text {st }}$ Century. Pretoria.

DARKWA O \& MAZIBUKO F. 2000. Creating virtual learning communities in Africa: challenges and prospects. [INTERNET: http://firstmonday.org/issues/issue5_5/darkwa/index.html.]

DEPARTMENT OF EDUCATION. 1997. Education White Paper 3: a programme for the transformation of Higher Education. Pretoria. 
DEPARTMENT OF EDUCATION. 2002a. The Restructuring of the Higher Education System in South Africa. Pretoria.

DRAFT WHITE PAPER on Higher Education. [INTERNET: http://www.polity.org.za/govdocs/white_papers/ educup3.html.]

FULLAN MG. 1993. Challenges and Problems. [INTERNET: http://www.ncrel.org/solrs/areas/issues/ educatrs/leadrshp/le5chall.htm.]

GREYLING L. 2001. Skills development: a strategic perspective. [INTERNET: http://inasp.org.uk/ajoljournals/ sajhe/vol15no2abs.html.]

JENKINS, J. 1989. Some trends in Distance Education in Africa. INTERNET: http://www1/worldbank.org/ DistEd/ Policy/National/diff-02.html. ]

KAHN T. 2002. Black universities likely to go. Business Day. 14, 12 February.

MALHERBE R \& BERKHOUT S. 2001. The national qualifications framework and the unconstitutional limitation of academic freedom. [INTERNET: http://inasp.org.uk/ajol/journals/sajhe/vol15no2abs.html.]

MONARE M. 2001. Asmal's master plan unveiled. The Star. 13, 7 March.

NCHE (NATIONAL COMMISSION ON HIGHER EDUCATION) 1995.a. NCHE: Systems, Governance, Funding process, progress and product. [INTERNET: http://star.hsrc.ac.za/nche/discuss/1.html.]

NCHE (NATIONAL COMMISSION ON HIGHER EDUCATION) 1995.b. NCHE: Systems, Governance, Funding working vision and definition of Higher Education. [INTERNET: http://star.hsrc.ac.za/nche/discuss/appendices.html.]

NCHE (NATIONAL COMMISSION ON HIGHER EDUCATION) 1995.(c). NCHE: Systems, Governance, FundingApartheid's Higher Education legacy. [INTERNET: http://star.hsrc.ac.za/nche/discuss/2.html]

NCHE (NATIONAL COMMISSION ON HIGHER EDUCATION) 1995.(d). NCHE: Systems, Governance, Funding - a single co-ordinated higher education system. [INTERNET: http://star.hsrc.ac.za/nche/discuss/6.html.]

PETERS 0. 1999. The university of the future: Pedagogical Perspectives. In Helmut Hoyer (ed.). The New Educational Frontier: Teaching and Learning in a Networked World. Proceedings of the $19^{\text {th }}$ World Conference on Open Learning and Distance Education, Vienna, June20-24, 1999. Oslo, Norway: The International Council for Open and Distance Education.

PORTER ME. 1985. Competitive Advantage: creating and sustaining superior performance. New York: The Free Press.

PRETORIUS JD. 2001. The higher education business - can it cope with international challenges. [INTERNET: http://inasp.org.uk/ajol/journals/sajhe/vol15no2abs.html.] 
REID IC. 1999. Online strategy in Higher Education. [INTERNET: http://ausweb.scu.edu.au/aw99/papers/ reid/paper.html.]

SAINT W. 1999. Tertiary Distance Education and Technology in Sub-Saharan Africa. Washington DC. ADEA (Working Group on Higher Education).

SIWEYA H. 2002. Higher Education held hostage by Asmal. The Star: 7, 20 May.

SMITF . 2000. Private Higher Education: shrouded in uncertainty. Outcomes, 1(2):8 November.

TSCHANG T. 1997. Macro issues and micro worlds: a conceptual framework for the virtual university. [INTERNET: http:///vulab.ias.unu.edu/hedu/ias-papers/edu/ted/hedu_vu.html.]

VAN DER MEER P. 2002. Stopping IEB exams will loner education standards. The Star: 7, 20 May.

VAN NIEKERK J. 2001. Adult Basic Education in South Africa from apartheid to democracy lessons learned and not learned. $8^{\text {th }}$ International Literacy and Education Research Network Conference on Learn ing. Spetses. 